\title{
Thermal Characteristics, Phytochemical and Functional Groups Assessment of Garcinia Kola as a Tropical Timber
}

\author{
Udeozo $^{1}$, I. P., Eboatu ${ }^{2}$, A. N., KELLE ${ }^{3}$ I. H. and Ejukwa ${ }^{1}$, E. E. \\ 'Department of Industrial Chemistry, Tanisan University Umunya, Anambra State, Nigeria. \\ ${ }_{2}^{2}$ Pure and Industrial Chemistry Department Nnamdi Azikiwe University Awka, Anambra State. \\ ${ }^{3}$ Department of Industrial Chemistry, National Open University Lagos, Nigeria.
}

\begin{abstract}
The elucidation of Garcinia Kola, (family: clusiaceae or guttiferae) timber was carried out in terms of thermal and physico-chemical techniques. Various physical and thermal tests performed on the timber: oven dry density, water imbibitions (at different time intervals: 30 mins, 5 hrs \& 24 hrs), thermal conductivity, electrical conductivity, afterglow time, flame duration, flame propagation rate, ignition time, moisture content and ash content showed that it's a good timber suitable for various construction purposes. The AAS of the sample showed the absence of As and the presence of some metals such as $\mathrm{Pb}, \mathrm{Na}, \mathrm{K}, \mathrm{Zn}, \mathrm{Ca}, \mathrm{Mg}, \mathrm{Cu}, \mathrm{Hg}$, and $C d$ in the decreasing order of the their concentrations. The TLC analysis gave Rf value of 0.53 and 0.55 in the chloroform-methanol and chloroform extracts respectively. Phytochemical screening showed the presence of Saponin, flavonoids, tannins, carbohydrate and resins. It also indicated the absence of steroid / terpenoids, alkaloids and protein. The Fourier Transform Infrared and Ultraviolet spectra suggested that the active compound might be an aromatic compound with $\mathrm{OH}, \mathrm{C}=S$ and $N-H$ group attached.

Key words: Garcinia Kola Thermal Characteristics, Phytochemical, Micro elements and Thin layer chromatography.

\section{Introduction}

Garcinia Kola is a species of flowering plant that belong to the clusiaceae or guttiferae family. It is a hardwood with bitter kola as its English name. Its natural habitat is subtropical or tropical moist low land forests. It is also a tree that grows in the rain forests of West and Central Africa. The fruit, seeds, nut and bark of the plant have been used for centuries in folk medicine to treat ailments from coughs to fever. According to a report from the centre for international forestry research, Garcinea Kola trade is important to the tribes and villages in Nigeria most especially the medicine men who believe in its purgative ${ }^{1}$. It resembles Atlanblackia Floribunda. It is well branched, evergreen and grown as a medium size tree, reaching $12 \mathrm{~mm}$ height in 12 years and has regular fruiting cycle, that is, the tree produces fruits every year. Garcinia Kola is one of the most important trees value in Nigeria for its medicinal seeds and its exploration in the natural forests has been very heavy. The seed of Garcinia Kola have pharmacological uses in treating cough, throat infections, bronchitis, hepatitis (inflammation of the liver) liver disorders ${ }^{2}$.
\end{abstract}

\section{Sample collection and Identification}

\section{Experimental}

Garcinia Kola timber was collected from timber shed at Nnewi in Nnewi North Local Government Area of Anambra State. Timber dealer, forest officer (Mr. Vin Okakpu of Nnewi Forestry) as well as literature ${ }^{3}$ helped in the timber identification.

\section{Sample preparation}

The timber was cut in a saw mill into two different shapes and sizes, dust from the timber was also collected. The timber was cut into splints of dimensions $30 \times 1.5 \times 0.5 \mathrm{~cm}$ and cubes of dimensions $2.5 \times 2.5 \times$ $2.5 \mathrm{~cm}$. The samples were dried in an oven at $105^{\circ} \mathrm{C}$ for 24 hours before the experiments.

\section{Method}

The thermal characteristics: Afterglow time, flame duration, flame propagation, ignition time, oven dry density, moisture content, water imbibitions, ash percentage, thermal conductivity and electrical conductivity were variously determined using American Society for testing and material (ASTM) methods ${ }^{4,5,6}$. The microelement composition was analysed using atomic absorption spectrophotometer model PG 990 manufactured by PG instrument Ltd U.S.A.

The phytochemical compounds: resins, steroids / terpenoids, tamin, alkaloids, carbohydrate and protein were qualitatively determined by the method outlined by Harbone ${ }^{7}$. 
The chloroform and chloroform-methanol extracts were monitored using TLC, Fourier Transform Infrared and Ultraviolet Spectroscopic methods.

\section{Result And Discussion}

RESULT

The results of the thermal investigation and the analysis of the active constituents present in the timber extract of Garcinia Kola are given in tables 1- 6 .

Table 1: Results of thermal characteristics of Garcinia Kola

\begin{tabular}{|l|l|l|}
\hline Characteristics & Units & Results \\
\hline Afterglow time & $\mathrm{Sec}$ & 347.33 \\
\hline Flame duration & $\mathrm{Sec}$ & 193.33 \\
\hline Flame propagation rate & $\mathrm{cm} .5^{-1}$ & $6.8 \times 10^{-2}$ \\
\hline Ignition time & $\mathrm{Sec}$ & 8 \\
\hline Over dry density & $\mathrm{g} . \mathrm{cm}^{-3}$ & $48.5 \times 10^{-2}$ \\
\hline Moisture content & $\%$ & 18.41 \\
\hline 30 mins Water imbibitions & $\%$ & 19.1 \\
\hline 5 hrs Water imbibitions & $\%$ & 35.8 \\
\hline 24 hrs Water imbibitions & $\%$ & 62.8 \\
\hline Ash Content & $\%$ & 0.72 \\
\hline Thermal conductivity & $\mathrm{Umoh}^{-1} \mathrm{~cm}$ & $10.92 \times 10^{2}$ \\
\hline Electrical Conductivity & $\mathrm{Sm}^{-1}$ & $2.9 \times 10^{-3}$ \\
\hline
\end{tabular}

Table 2: Micro elemental composition \%

\begin{tabular}{|l|l|}
\hline Zinc & 0.2 \\
\hline Lead & 1.92 \\
\hline Cadmium & 0.008 \\
\hline Copper & 0.02 \\
\hline Sodium & 0.81 \\
\hline Calcium & 0.13 \\
\hline Magnesium & 0.08 \\
\hline Potassium & 0.66 \\
\hline Arsenic & Nil \\
\hline Mercury & 0.01 \\
\hline
\end{tabular}

Table 3: Phytochemical composition of Garcinia Kola

\begin{tabular}{|l|l|}
\hline Class of phytocompounds & Inference \\
\hline Saponin & ++ \\
\hline Flavonoids & +++ \\
\hline Resins & + \\
\hline Steroids / terpenoids & - \\
\hline Tannin & ++ \\
\hline Alkaloids & - \\
\hline Carbohydrate & ++ \\
\hline Protein & - \\
\hline
\end{tabular}

Key $\quad+++\quad-\quad$ highly present

$+\quad-\quad$ moderately present

$+\quad-\quad$ absent slightly present

Table 4: Results of Thin layer chromatographic characteristics of chloroform- methanol and chloroform extracts.

Wave number $\left(\mathrm{cm}^{-1}\right)$

\begin{tabular}{|l|l|l|}
\hline Sample & Number of spot & Rf value \\
\hline Chloroform-methanol extract. & 1 & 0.529 \\
\hline Chloroform extract & 1 & 0.546 \\
\hline
\end{tabular}

Tables 5: Results of Fourier Transformed Infrared and Ultraviolet spectra of Chloroform

\begin{tabular}{|c|c|}
\hline 3426 & O-H stretch for alcohol \\
\hline 2103 & $\mathrm{C}=\mathrm{C}$ stretch for alkynes \\
\hline 2087 & $\mathrm{~N}=\mathrm{C}=\mathrm{S}$ stretch for Isothiocyanate \\
\hline 1652 & $\mathrm{C}=\mathrm{O}$ stretch for primary \\
\hline 1527 & $\mathrm{~N}=\mathrm{O}$ stretch for nitro group \\
\hline 1020 & C - O stretch for Isothiocy anate \\
\hline $\mathrm{UV}_{\text {max }} 204,217,228,245$ and 280 & Indicating highly conjugated isoquinoline amide. \\
\hline
\end{tabular}


Table 6: Result of Fourier Transformed Infrared and Ultraviolet Spectra of Chloroform - methanol extract.

\begin{tabular}{|l|l|}
\hline Wave number $\left(\mathrm{cm}^{-1}\right)$ & Suspected chromophores \\
\hline 3436 & N $-\mathrm{H}$ stretch for secondary amines or primary amides \\
\hline 2091 & $\mathrm{~N}=\mathrm{C}=\mathrm{S}$ stretch for Isothiocyanate \\
\hline 1643 & $\mathrm{C}=\mathrm{C}$ stretch for alkene \\
\hline 1444 & C $-\mathrm{H}$ stretch for alkane \\
\hline 1105 & C - O stretch for secondary \\
\hline 1023 & C O stretch for vinyl ether \\
\hline $\mathrm{UV}_{\max } 220,233,259,267,276,284,293,305,594$ and 648. & Indicating highly conjugated trisubstituted aromatic compound. \\
\hline
\end{tabular}

\section{Discussion}

The five characteristics analysis carried out on the wood of Garcinia Kola showed that it had low afterglow time (less than five minutes) which made it less hazardous in fire situations because it wouldn't glow long enough for rekindle to take place. Its flame duration value indicated that it can sustain combustion. Water imbibitions at 30 mins, $5 \mathrm{hrs}$ and $24 \mathrm{hrs}$ interval showed the capacity of Garcinia Kola wood to absorb water over a period of time. The ash content value is in line with the ascertain of Desch and Dinwoodie (1981) who stated that timbers that possess small ash content are suitable in their use as a source of carbondioxide for internal combustion engine. One can deduce from the result that Garcinia Kola is a hardwood that will be very good for construction and other purposes. The result of the phytochemical analysis showed the presence of saponin, resins, tannin, carbohydrate and flavonoids as the major components. The medicinal values of medicinal plants lies on these phytocompounds and such produce definite physicological actions in human body. Flavonoids exhibit an anti-inflammatory, anti-allergic effects, analgesic and anti-oxidant properties ${ }^{10}$. Herbs that contain tannins are astringent in nature and are used for treatment of intestinal disorders such as diarrhea and dysentry ${ }^{11}$. Also, the presence of tannin in the extract of the plant must have informed its use by many traditional medicine practioners in the treatment of wounds and bruises which is in line with the finding of some researchers ${ }^{9}$.

The result of the Atomic Absorption Spectrophotmetric analysis of the sample is very encouraging Copper, calcium, potassium and magnesium were present and are involved in body enzymatic activities. Sodium which help in $\mathrm{P}^{\mathrm{H}}$ balance of body fluids, mercury, cadmium, lead and zinc were also present while arsenic is absent.

The absorption in the ultraviolet visible spectra and FTR spectra suggested that the active compound might be an aromatic compound with $\mathrm{OH}, \mathrm{C}=\mathrm{S}$ and $\mathrm{N}-\mathrm{H}$ group attached.

\section{Conclusion}

The results of thermal characteristics, phytochemical and AAS analysis of the woods of Garcinia Kola had confirmed that it contain some components of medical value and as well as good material for various construction works. The UV and IR spectra show that it contains some bioactive compounds. Phenol represented in IR and UV spectra confirmed the presence of tannins and therefore, the plant can give instant relief when applied on burns or injured skins among other numerous uses. The presence of flavonoids, $\mathrm{Ca}$ and $\mathrm{Mg}$ from AAS analysis confirmed its anti-inflammatory and anti-oxidant effect.

It is recommended that the anti-microbial properties of the timber extracts be elucidated.

\section{References}

[1]. Farombi, E.O and Emerole, G.O., (2005): Chemopreventation of aflatoxin Bi-induced genotoxicity rats by Kolaviron, a Natural bioflavonoid of Garcinia Kola seeds Eur J Cancer Prev. 14(3): 207 - 214

[2]. Olajide, O.J., Adeniyi, P.A, (2011):, Studies on effect of aqueous Garcinia Kola extract on the lateral geniculate body. Wistar publish Lagos. Journal, Machem Journal Vol. 7(3) 44-50

[3]. Keay R.W.J., Onochie C.F.A. and Stanfield D.P. (1964): Nigeria Trees, Department of Forest Research Publishers Ibadan. Vol 1, pp 38-265.

[4]. American Society for Testing and materials, 1998b. standard test methods for five tests of building construction and materials. Designation E1 19-98. West Conshohocken, PA: ASTM.

[5]. American Society for Testing and Materials 1999a. Direct moisture content measurement of wood and wood-based materials. Designation D4442-99. West Conshohocken, PA: ASTM.

[6]. American Society for Testing and Materials, 1998b. Standard test methods for five tests of building construction and materials. Designation E1 19-98. West coshohocken, PA:ASTM.

[7]. Harbon, J.B. (1998). Phytechemical method $3^{\text {rd }}$ edition. Thomson science 2-6 Boundary Row London, UK pp 1-290.

[8]. Desch H.E and Dinwoodie J.M. (1981): Timber, its structure, properties and utilization, macmillian press ltd, London, $6^{\text {th }}$ Edition Pp $155-208$.

[9]. Gills, L.s. (1992): Ethnomedical uses of plants in Nigeria UNIBEN Press, Benin City, Pp36-42.

[10]. Dunguid, J.P., Marmoid, B.P. and Swain, R.H.A. (1989): Mackie and Maccartney's Medical Microbiology $13^{\text {th }}$ ed, Vol. 1. Churchill Livingstone London, P163.

[11]. Akpulu, I.N., (1994): Assay of Antimicrobial Activity of plant. Nigeria Journal of Biotechnology, 33,18.

[12]. Udeozo I.P., Eboatu A.N., Arinze, R.U. and Okoye, H.N. (2011); Some fire characteristics of fifty-two Nigerian Timbers. Anachem Journal Vol. 5 (1), 920-927. 